Meta

Journal des traducteurs

Translators' Journal

\title{
The Making of a "Correct" Translation Showcasing the Official Chinese Discourse of Translation
}

\section{Yong Zhong}

Volume 56, numéro 4, décembre 2011

URI : https://id.erudit.org/iderudit/1011253ar

DOI : https://doi.org/10.7202/1011253ar

Aller au sommaire du numéro

Éditeur(s)

Les Presses de l’Université de Montréal

ISSN

0026-0452 (imprimé)

1492-1421 (numérique)

Découvrir la revue

Citer cet article

Zhong, Y. (2011). The Making of a "Correct" Translation Showcasing the Official Chinese Discourse of Translation. Meta, 56(4), 796-811.

https://doi.org/10.7202/1011253ar
Résumé de l'article

L'objet du présent article est la traduction des textes à contenu politique en Chine. La question est abordée par le biais d'une étude de cas, à savoir les traductions de préceptes récemment formulés en 2006 par le chef de l'État chinois, Hu Jintao 胡锦涛. Comme de nombreux préceptes par le passé, ceux-ci ont été traduits à maintes reprises en anglais. Quatre des traductions sont présentées, certaines paraissant « justes » et d'autres, «fautives ». La comparaison des différentes traductions mène à poser un certain nombre de questions, y compris ce qui caractérise une traduction « juste ", la manière de la produire, les stratégies permettant d'atteindre cette « justesse » et quels sont les critères de validité propres à la Chine. L'auteur espère que cet article contribuera à mieux faire connaître le discours chinois dominant et la manière dont la traduction est organisée, réglée et évaluée en Chine. 


\title{
The Making of a "Correct" Translation Showcasing the Official Chinese Discourse of Translation
}

\author{
YONG ZHONG \\ University of New South Wales, Sydney, Australia \\ y.zhong@unsw.edu.au
}

\begin{abstract}
RÉSUMÉ
L'objet du présent article est la traduction des textes à contenu politique en Chine. La question est abordée par le biais d'une étude de cas, à savoir les traductions de préceptes récemment formulés en 2006 par le chef de l'État chinois, Hu Jintao 胡锦涛. Comme de nombreux préceptes par le passé, ceux-ci ont été traduits à maintes reprises en anglais. Quatre des traductions sont présentées, certaines paraissant «justes» et d'autres, «fautives ». La comparaison des différentes traductions mène à poser un certain nombre de questions, y compris ce qui caractérise une traduction «juste», la manière de la produire, les stratégies permettant d'atteindre cette «justesse » et quels sont les critères de validité propres à la Chine. L'auteur espère que cet article contribuera à mieux faire connaître le discours chinois dominant et la manière dont la traduction est organisée, réglée et évaluée en Chine.
\end{abstract}

\begin{abstract}
This paper studies political translation in contemporary China. It approaches the issue by tackling a case study of the translations of a maxim issued in 2006 by the Chinese supreme leader, Hu Jintao 胡锦涛. Like many past maxims, this one has been translated many times into English and four of the renditions are sampled for the case study, including seemingly "correct" and "flawed" ones. By comparing the different renditions, the study has managed to address a number of questions, including what makes a "correct" translation, how a "correct" translation is made, what strategies are used to accomplish "correctness" and what the criteria are for the making of a "correct" translation in China. The author hopes that this paper will contribute to an enhanced knowledge with regard to the dominant Chinese discourse of translation and about how translation is organized, regulated and evaluated in China.
\end{abstract}

\section{MOTS-CLÉS/KEYWORDS}

traduction politique, style, fidélité, traducteur officiel, «Les Huits Honneurs et les Huit Hontes $>$

political translation, style, fidelity, official translator, "The Eight Honours and Eight Shames"

\section{Leadership Qualities of Chinese Party State Leaders}

"Leadership involves getting people to do things that they usually would not want to do" (Cherniss 2006: 144), though not every national political leader is able to do this effectively. Usually, those who are able to do this have a range of qualities, which can be singled out and provide fundamental lessons for current and future leaders (Nye 2008). Some of these qualities are considered to be crucial across societies and 
cultures albeit to varying degrees and subject to different value judgements (Grove 2007). They include three distinct ones, which are of special relevance to this paper: the ability to vision changing conditions in order to improve (Baumgartner 1989, Grove 2007, Nye 2008), the ability to communicate visions (Gardner and Laskin 1995), and charisma (Cherniss 2006, Nye 2008). There are others, e.g., national loyalty (Midlarsky 1989, Nye 2008), which is of less immediate relevance to the discussions of this paper and so this paper will not delve into in them. ${ }^{1}$

These known leadership qualities are arguably present in the supreme leaders, past and present, of the Party State of modern China. With regard to visioning, even though they may not always have had the desired flexibility and honesty to admit past mistakes and criticisms, these leaders have been able to continuously adapt to changing conditions and reshape China according to their visions depicted in published works. Examples of the works include the five-volume Mao Zedong's Selected Works (Mao 1991), the three-volume Deng Xiaoping's Selected Works (Deng 1993) and the three-volume Jiang Zemin's Selected Works (Jiang 2006). The current supreme leader Hu Jintao has yet to have his Selected Works written up, edited and published. But he is apparently busy formulating and spreading his own messages including The Eight Honours and Eight Shames (八荣八耻) (abbreviated to “Honours/Shames" in this paper).

In the aspect of communicating visions, the past and the present supreme leaders of the Chinese Party State have always propagandized actively. It is important to note that, as Sun (1996) points out, propaganda is not seen as an evil practice in communist China. For example, a billion copies of Mao Zedong's Selected Works, including some editions known as Mao Tse-tung's Selected Works, alone were printed and distributed across the nation and the world. ${ }^{2}$ In addition to quantity, special efforts were made to enhance the communication effect. The five-volume original works by Mao were re-edited into The Little Red Book so that people had something easy to pocket, to carry, to read, to chant, to exchange and to disseminate. This pocket-sized edition itself sold 5 billion copies. ${ }^{3}$ Furthermore, Mao used the kind of language, including discursive devices (e.g., dichotomy) and rhetoric structures (e.g., antonyms, repetition and symmetry), which could be easily restructured into plain, rhymed and rhythmic phrases, maxims and slogans in order for his messages to be maximally accessible by the masses. To exemplify the language he used and also to show a possible discursive (i.e., the way of articulating reality) link to "Honours/ Shames," I quote his "Six Criteria," translated at a time when he was known to international readers as Mao Tse-tung, with regard to the handling of interpersonal conflicts: ${ }^{4}$

(1) Words and actions should help to unite, and not divide, the people of our various nationalities.

(2) They should be beneficial, and not harmful, to socialist transformation and socialist construction.

(3) They should help to consolidate, and not undermine or weaken, the people's democratic dictatorship.

(4) They should help to consolidate, and not undermine or weaken, democratic centralism.

(5) They should help to strengthen, and not discard or weaken, the leadership of the Communist Party. 
(6) They should be beneficial, and not harmful, to international socialist unity and the unity of the peace-loving people of the world.

As to the third leadership quality, the charisma of the Chinese Party State leaders is often expressed by cultivation in literature and other cultural pursuits as well as political and military prowess. Mao Zedong who was seen as arguably the greatest ruler in modern Chinese history was known to be proficient in poetry and calligraphy, which according to Barmé (1996) and Ma (2006) facilitated the articulation and spread of his vision. Presumably, artistic cultivation can distinguish a ruler from his peers by making him appear less threatening (Bloodworth 1982). Olesen (2006), who first quoted "Honours/Shames" at Associated Press (AP), observed that "for centuries, Chinese leaders have tried, usually in vain, to mould public and official behaviour with poetic maxims"5. Leaders with only military accomplishments but without demonstrated literary/cultural talents have often appeared to be imperfect rulers. Mao Zedong himself belittled the emperors of Qian, Han, Tang, Song and Yuan Dynasties for lacking artistic cultivation or poetic talent. I quote from his 1939 poem Snow: ${ }^{6}$

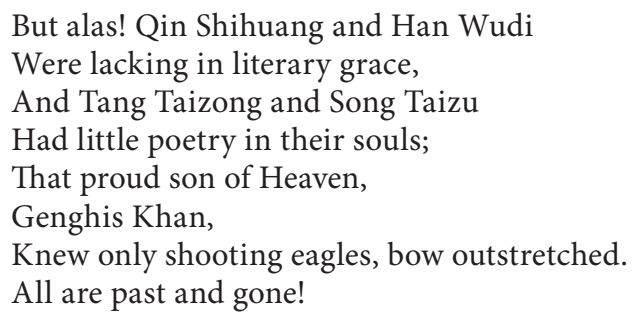

The poem was penned in 1939 and presumably translated into English during the rule of Mao Zedong as Chairman of PR China (1949-1976). Like all those responsible for the officially published translations of Mao's works, the translator of the poem has remained anonymous.

\section{Is “Correctness” Another Leadership Quality?}

"Correctness," which is not a commonly discussed attribute of leadership in academic literature, has been a seemingly inherent and natural quality of leaders in the dominant political and social discourse in modern communist China. It justifies the oneparty rule system on the premise of the Chinese Communist Party being "the Great, Glorious and Correct Party," a slogan chanted anytime anywhere under Mao's rule and still audible in today's China. It rationalizes the many internal frictions and conflicts as "struggles between correct and wrong political lines," also Chinese communist cliché. It prescribes the norm of language and behavior of the subjects according to the will of the Party leaders. Thus, "Honours/Shames" has been divinized as the "correct sense of honours and shames," "correct values" and "correct norms of behavior" in recent official propaganda.

"Correctness" has also been a prominent requirement for translation of works by political leaders in the dominant discourse of translation in China. "Honours/ Shames" has been translated time and again mainly because of the need to convey the leader's maxim correctly and also because of a desire to show to other translators how translation should be done (Ding 2006). In other words, "correctness" in trans- 
lation assumes a leadership attribute too, as both an instrument of the leaders and as an authority of standardization.

However important it is, "correctness" is a prescriptive rather than an intellectual concept and it is much more difficult to capture and define academically than vision, communication and charisma. Many ordinary Chinese are aware of this capricious nature of the concept, giving rise to the satirical popular saying: I (i.e., the authority) say you are correct and you are correct; you are correct even if you are incorrect; I say you are incorrect and you are incorrect; you are incorrect even if you are correct.

As an academic, I am not able to define "correctness" in relation to political leadership. Nor am I able to provide a solid definition of "correct" translation. Nor do I think that those "correct" translators discussed in this paper can offer a more scientific definition of "correct" translation. However, through some objectivelooking analysis, I have actually discovered a formula for producing a "correct" translation, which will be presented in the second half of this paper.

\section{Another Supreme Maxim}

On 4 March, 2006, "Honours/Shames"7 was officially pronounced for the first time by $\mathrm{Hu}$ Jintao, the Secretary General of the Chinese Communist Party (CCP) since 2002, Chairman of the People's Republic of China since 2003 and the Commander General of the People's Liberation Army since 2004. It formed part of Hu's address to an assembly of senior officials representing two other political parties at the $4^{\text {th }}$ plenary meeting of the $10^{\text {th }}$ National Committee of the Chinese People's Political Consultative Conference (CPPCC). CPPCC comprises mainly representatives of the many minuscule parties permitted by the CCP to survive under its sole leadership and usually holds national meetings before or after a CCP national congress to preview and endorse whatever decisions CCP has already made or is about to make. The $4^{\text {th }}$ CPPCC plenary meeting was held for the parties to learn about policy changes to be finalized on the $17^{\text {th }}$ Congress of CCP, which carried the theme of "scientific and harmonious developments." Previously, CCP had been single-minded about economic expansion, which was responsible not only for the doubling of the national GDP every 5 years since late 1980s or so but also for disastrous damages to the environment and for major social problems (e.g., polarization between the rich and the impoverished).

At first sight, "Honours/Shames" appears like an ordinary list of morals and factual-looking statements about some seemingly universalist moralities and values in China regarding what is honourable or shameful behaviour. But there is more to the maxim than a first sight can spot if it is seen in the light of speech act theory. According to Austin (1975), all utterances comprise two basic aspects of meaning, i.e., the conventional meaning of the sentence and the speaker's intended speech act. Speech does not just describe but also performs actions. Issued by the current supreme ruler of China and addressed to his subjects, the maxim not only describes "honour" and "shame" but also involves acts and actions, including those of addressing subjects and giving commandments for the purpose of governing. It basically specifies a list of do's and don'ts for the Chinese citizens by setting the boundaries of honourable and shameful behaviours. Some of the listed shameful behaviours (e.g., harming motherland) are indictable offences and can be prosecuted under the pretext 
of "crimes of dividing the motherland" in line with the current constitutions. In fact, a good number of people have been convicted of the crime in recent years in China. But many others are sourced from traditional and popular morals and clichés, including 服务人民 (serving the people), 辛勤劳动 (diligence), 诚实守信 (honesty) and 遵纪守法 (being disciplined). Still others, including especially 崇尚科学 (worshipping science), are important to the current regime as they are meant to signal progress of vision from its predecessors as well as to justify its legitimacy.

As well as specifying the do's and don'ts, "Honours/Shames" is also noteworthy with regard to its formal style. Even though it is hailed as a new vision of the Chinese communist leaders, it inherits much of the discourse and rhetoric of the bygone predecessors. Like Mao's "Six Criteria," it is phrased in discursively and rhetorically loaded language (e.g., dichotomy, antonyms, repetition and symmetry) rather than in straightforward plain language. The rhetorical devices built into the maxim include: the use of dichotomy (i.e., between "honour" and "shame") in eight pairs of statements, syntactic symmetry and repetition in the structure of the statements, the strict use of seven characters in each statement and the inclusion of many fourcharacter idioms (e.g., 见利忘义 literally meaning “seeing benefit forgetting correct behaviour") containing allusions to ancient personalities, legends and wisdom (e.g., 见利忘义 was a quotation sourced from a book authored by Ban $\mathrm{Gu}$, a historian born $32 \mathrm{AD})$. I would like to add that the importance of the maxim might have induced some Chinese translators and translation scholars to read excessive cultural heritage into the text. For example, while I regard 见利忘义 (“seeing benefit forgetting correct behaviour") in the maxim as a mere idiom and even a cliché, Lin reads into it "an ancient, profound wisdom of Chinese civilization first developed by Mencius... which cannot be articulated in English" (2006: 81). In short, the language of the maxim may seem unnecessarily repetitive, excessive or pedantic, but fluency in using them arguably contributes to the charismatic look of their users, as noted previously.

By pronouncing the maxim, Chairman $\mathrm{Hu}$ signals his desire to rule by honouring or shaming his subjects, i.e., not only by the gun, or by/through the law - arguably the new fashion, but importantly also by his supreme set of morals. In other words, "Honours/Shames" is not an ordinary literary text. It has many political, social, moral and artistic functions. Politically it exudes authority, addresses the whole of the population in its jurisdiction, gives commandments and justifies power and oneparty rule. Morally, it delineates morality, marks behavioural boundaries and defines what is right and what is wrong. Artistically, it is meant to charm, enchants and showcases talent and cultivation.

\section{Translations of Chinese Leaders into “Other” Languages}

As written in the beginning, there is a tradition of translating and spreading the works of the Chinese Party State leaders, because this is "an officially sanctioned project of exporting literature and ideology since 1950s" (Ma 2006: 17) and is about "fostering an understanding in the foreigners about Chinese situations and policies" (Chang 2004: 55). The "Honours/Shames" has merely continued this tradition and there is nothing unusual or sinister about it. In fact, political, social and cultural heavy weights of most influential countries have been and continue to be translated into foreign languages. What is really unusual about the Chinese tradition? It is the 
scale of input into this Chinese project and the identity of the translators as well as the excessive size of output.

With regard to the input, the project of translating Chinese leaders into foreign languages has utilized huge government resources, engaged the cream of translators of the country and produced massive output distributed to all corners of the world. $\mathrm{Ma}$ (2006) presented an interesting case study involving translation of Mao's writings, centrally organized, supervised, distributed and funded with national resources, comparable to the translation of the Bible and Buddhist sutras.

As to the identity of the participant translators, they were all official translators employed by the Party State to which their loyalty supposedly belongs. Many of them had the best available foreign language education and were cadres of China Foreign Languages Bureaus. Others were renowned scholars (e.g., Yang Xianyi who translated Dream of Red Mansion into English) and cultural celebrities (e.g., Zhao Puchu, head of All China Bhuddist Associate) purposefully recruited from universities, research institutes and other organizations. A most recent example is Hengqi Ding, much quoted in this paper for authoring a "correct" translation of the "Honours/Shames." He has been a professor and dean in University of International Business and Economics, a Chinese Consul General to San Francisco, Executive of All China Translators' Association, an editor of Chinese Translators Journal and an executive counsellor of China International Translation and Publishing Corporation. On the basis of their official affiliation and loyalty, I refer to them as "official" translators in contrast to professional translators many of whom work on a free-lance basis both in China and internationally. In short, the official translators hold senior official positions in political and/or professional organs, are mandated to work for the interest of the Party and exert influences over the translation profession.

In fairness, there were also a couple of native English "experts" (e.g., W. J. F. Jenner) involved with the Chinese political translation project. Occasionally advice was also sought from communist sympathisers (e.g., Anna Louise Strong ${ }^{8}$ ). But the bulk of the into-foreign language translation was completed by native Chinese translators. As a result, the outcome was often not very English-looking and failed to register much impact on the target readers (Cheng 2004, Ma 2006). Jenner, who contributed to the project as a foreign expert, commented that "the job is really one that we Anglophones should have been doing for ourselves" (Jenner 1990: 187).

The massive input and identity of the translators led to, among other outcomes, a phenomenal output on the one hand and linguistic/cultural inaccessibility on the other. Mao's Little Red Book was translated into 37 foreign languages and over 10 million copies of translation sold to 182 countries (Wei 2004) and Mao Zedong's Poems was translated into 16 languages, including multiple translations in major foreign languages like English and French (Yang 1999).

\section{Translating "Honours/Shames"}

China appears to be making apparent progress towards so-called socialist democracy and the rule through/by the law. Nevertheless, what the current supreme leader says continues to be so important that the whole nation has to stop to hear it, catch it, study it, chant it, understand it and propagandise it. After "Honours/Shames" was released, intensive and extensive study sessions were held nationally so that party 
members, cadres, public servants and especially teachers and students could recite and memorize the maxim. For example, Zhang ${ }^{9}$ reported that, over a period of three months, Tianjin-based Nankai University organized all its staff and students to "carefully study, propagate and implement Chairman Hu's saying by blending it into textbooks and classroom learning and by injecting it into staff and students' brains." Some Chinese educators, e.g., Wenchao He went further by recommending that "Honours/Shames" form part of the character formation in the Chinese education system..$^{10}$ Efforts were also made to merge the maxim into the teaching of English and translation. ${ }^{11}$

Furthermore, the maxim must have been important for the Chinese propaganda departments, translators and translation profession too, even though the much changed China now appears to be investing less in political translation and publishing. Many renditions have been produced, including the ones sampled in this paper, thanks to the great efforts by state apparatus like Xinhua News Agency, China Foreign Language Bureau and Foreign Ministry; official scholarly institutions like Translators Association of China (TAC) and Chinese Translators Journal; and official professionals like Ding and Lin, both of whom are much quoted in this paper. Sometime in the middle of the commotion, New York-based AP reported on the maxim and produced its own translation though I don't know if there is any link between its translation and that of Xinhua News Agency. Table 1 provides a timeline of the translation activities revolving around the maxim.

TABLE 1

\section{Timeline of "Honours/Shames" translations}

\begin{tabular}{|c|c|}
\hline 4 March, 2006 & Maxim first uttered by Chairman $\mathrm{Hu}$ \\
\hline 8 March, 2006 & Maxim first published in translation by Xinhua News Agency \\
\hline 16 March, 2006 & $\begin{array}{l}\text { Maxim quoted in English translation by Alexa Olesen and published by } \\
\text { Associated Press }\end{array}$ \\
\hline April, 2006 & $\begin{array}{l}\text { Competition organized by Translators' Association of the Chinese Foreign } \\
\text { Ministry to translate the maxim }\end{array}$ \\
\hline April, 2006 & Maxim translated by Mr Hengqi Ding \\
\hline April, 2006 & $\begin{array}{l}\text { Ding's translation discussed in the half-yearly symposium organized by } \\
\text { Propaganda and Translation Committee of All China Translators }\end{array}$ \\
\hline May, 2006 & $\begin{array}{l}\text { Association, forming the basis of the official translation of the maxim } \\
\text { "Official translation" of the maxim published by Chinese Translators' Journal } \\
\text { (China Translators' Association 2006: 95) }\end{array}$ \\
\hline 29 June, 2006 & Lin submitted his further perfected translation to Chinese Translators' Journal \\
\hline September, 2006 & Lin's translation published by Chinese Translators' Journal (Lin 2006: 80) \\
\hline
\end{tabular}

But, even if the supreme Chinese leader authored it and even if it has been translated many, many times, is there anything special in the maxim and its many renditions, which warrants academic attention? Isn't it true that politicians everywhere say all sorts of things all the time? Some make sense, are translated and change the lives of their subjects and foreign readers positively. Some make sense, are translated but fail to change the lives of their subjects or foreign readers significantly. Many others simply sound weird, are weird and are rarely heeded to or remembered no matter how many times they have been translated. In today's China, people no longer feed or cloth on political slogans only, average translators do not usually live on 
official services and officially correct version of reality is not always believed in. So, whether or not a regal maxim is translated many times, what is in it for translation researchers and critics?

I see great academic benefits in studying different renditions of a regal maxim. A great benefit is an enhanced understanding of the mainstream Chinese discourse of translation of which "correctness" is such a crucial concept. For example, by comparing renditions considered "correct" to those seen as "flawed," we can better appreciate what would make a correct translation, what elements or what strategies must be used to accomplish "correctness" and "fidelity" and what criteria or benchmarks are used for translation evaluation in China. Another benefit is an enhanced understanding of how translators relate to the government and the professional association; how translation is organized, regulated and evaluated; and how translators and translations impact on the Chinese society, etc.

In the next section, I will present "Honours/Shames" in Chinese language, followed by three sampled published renditions as well as a word-for-word rendition, which I have personally authored in this paper in order to facilitate an appreciation by English language readers of what the maxim is all about.

\section{The Maxim, a Word-to-Word Rendition and three Published Renditions}

I present, in temporal sequence, the "Honours/Shames" in Chinese, followed by four English renditions of "Honours/Shames" sampled for analysis and discussion. I authored Rendition [1], which is a word-for-word translation of the maxim intended for the benefit of my English readers. Rendition [2] is the work of Xinhua News, which is rather comparable in syntactic and rhetorical structure to the Associate Press version. The latter is not included for lack of space and also for the purpose of not comparing translations by native and non-native writers, which might be seen as unfair to the latter. The Xinhua and AP version are criticized by official Chinese translators (i.e., Ding and Lin) as flawed. Rendition [3] is the work of TAC and is based on a draft by Ding. I have not included Ding's version because it is hardly different from the TAC version except with regard to word choices. For example, where Ding wrote "prefer to be ignorant" and "violate laws and disciplines," TAC wrote "refuse to be educated" and "are undisciplined and break the law" respectively. And the two renditions are of exactly the same length, both having 145 words. Rendition [4] is translated by Lin, an official translator. He acknowledges that his translation has been informed by the TAC version and claims that his version and the TAC version are superior to and more correct than the preceding ones. When re-printing Renditions [2], [3] and [4], I have tried to keep the typography of the originals, including especially the punctuations and line splitting. I have also indicated the number of words used in each rendition in brackets at the end of each sample, which will be useful when I discuss minimalist and maximalist translation styles.

\footnotetext{
八荣八耻

以热爱祖国为荣、以危害祖国为耻, 以服务人民为荣、以背离人民为耻, 以崇尚科学为荣、以愚昧无知为耻, 以辛勤劳动为荣、以好逸恶劳为耻,
} 
以团结互助为荣、以损人利已为耻, 以诚实守信为荣、以见利忘义为耻,

以遵纪守法为荣、以违法乱纪为耻, 以艰苦奋斗为荣、以骄奢淫逸为耻。

\section{Rendition [1] (84 words)}

Loving motherland as honour, harming motherland as shame

Serving people as honour, deserving people as shame

Worshipping science as honour, foolishness ignorance as shame

Diligent labour as honour, loving comfort hating work as shame

Unity mutual help as honour, harming others self-benefiting as shame

Honesty keeping promises as honour, seeing profits forgetting integrity as shame

Discipline law abiding as honour, breaking law messing discipline as shame

Hardship struggle as honour, pretentiousness extravagance sensuality comfort as shame

(Translated by the author)

\section{Rendition [2] (71 words)}

Love the Motherland, do her no harm.

Serve the people, never betray them.

Follow science, discard fatuity.

Be diligent, not indolent.

Be united and help each other, make no gains at others expenses.

Be honest and trustworthy, do not spend ethics for profits.

Be disciplined and law-abiding, not chaotic and lawless.

Live plainly and work hard, do not wallow in luxuries and pleasures.

(Xinhua News Agency, quoted in Lin 2006: 80)

\section{Rendition [3] (145 words)}

Honour to those who love the motherland, and shame on those who harm the motherland;

Honour to those who serve the people, and shame on those who betray the people;

Honour to those who quest for science, and shame on those who refuse to be educated; Honour to those who are hardworking; and shame on those who indulge in comfort and hate work;

Honour to those who help each other, and shame on those who seek gains at the expense of others;

Honour to those who are trustworthy, and shame on those who trade integrity for profits;

Honour to those who abide by law and discipline, and shame on those who break laws and disciplines;

Honour to those who uphold plain living and hard struggle and shame on those who wallow in extravagance and pleasures.

(Translators Association of China)

\section{Rendition [4] (139 words)}

Honour to those who love the motherland,

Shame on those who harm the motherland.

Honour to those who serve the people,

Shame on those who betray the people.

Honour to those who believe in science,

Shame on those who choose to remain ignorant.

Honour to those who are hard-working,

Shame on those who are lazy and avoid work. 
Honour to those who uphold unit and help one another,

Shame on those who seek personal gain at others' expense.

Honour to those who are honest and trustworthy,

Shame on those who trade principle for profit.

Honour to those who are disciplined and law-abiding,

Shame on those who are undisciplined and break the law.

Honour to those who practice plain living and defy adversity,

Shame on those who indulge in extravagance and pleasure-seeking.

(Lin 2006: 80)

Lin split each pair of "honour" and "shame" into two separate lines. The structure of the rendition has been reproduced for the purpose of facilitating the discussion of the symmetry in Lin's translation.

\section{Managing the Difficult Task of Translating the Maxim Correctly}

"Honours/Shames" is the text to translate and, more importantly, it is the text to translate correctly. But it is also a difficult text to tackle by any translators. To begin with, it is a political text authored by the supreme leader of China and it can be politically consequential if any "incorrect" translation is produced. The official translators must have been fully aware of the political significance and consequence of their mission. Ding (2006) and Lin (2006) both stated that "Honours/Shames" must be translated in strict conformity to the criteria of 信 (accuracy), 达 (fluency), 雅 (beauty), ${ }^{12}$ especially 信 (accuracy). Furthermore, English renditions of political texts must also be 雅 (elegant), i.e., idiomatic and looking good in English and free of socalled "Chinglish," i.e., Chinese style English. But the problem is, as most real-life translators know, that accurate translation is difficult and accurate and elegant translation of important political texts is even more difficult, not to mention that the two criteria may actually contradict each other. I quote Wang, a career translator of China Central Translator Bureau, Director of Chinese Ministry of Foreign Affairs and former Chinese ambassador to Papua New Guinea:

Fidelity is the basic requirement of political translation. Political texts concern State matters and every word has been thoroughly repeatedly weighed before it is finalized. Every sentence and every word has precise meaning that must be reflected accurately in translation. No distortion is allowed. Translators must strike a perfect harmony and unity between accurate language and idiomatic language within a limited time frame. (Wang 2004: 56)

What makes political translation even more difficult is the style of language in which Chinese leaders often deliver their messages. They do not just speak or write but also quote, chant and copy idioms, poems, prose and allegories often sourced from ancient literature (Barmé 1996; Ma 2006; Olesen 2006). According to Qiu (2004), a senior career translator of Chinese Ministry of Foreign Affairs, this greatly increases the difficulty of translation. "Honours/Shames" epitomizes that difficulty. As well as stating the current supreme leader's vision, it also embeds an "ancient, profound wisdom of Chinese civilization first developed by Mencius (372-289 B. C.) and now expanded by the Chinese communist party" (Lin 2006: 80). It is structured in "symmetry" and "audiovisual beauty" (Ding 2006) and "possesses rich and beautiful rhetorical features" of the ST (Lin 2006: 81). It is extremely difficult to "strike a 
perfect harmony and unity between accurate language and idiomatic language." According to Lin (2006), translator of Rendition [4], Renditions [2] is "unrefined and flawed because it failed to manage the difficulty."

As a translation practitioner and academic, I myself believe that the difficulties are simply too many and too profound to be overcome completely. The heavily loaded content and form of the maxim simply cannot be transplanted to impact on English readers in exactly the same manner and quality as the ST may have on the Chinese readers. I would rather share the now increasingly more pervasive belief about a selectively functional rendition being more feasible than a "correct" one, as articulated by Savory (quoted in Gutt 2000: 393) and Bell (1991). I speculate that the translators of Rendition [2] understandably had a journalist mission to fulfil and had to struggle with real-life pressure including a tight schedule and limited media space/ time. They must have appreciated the difficulty in producing a "correct" translation and so consciously decided to translate selectively, focusing on the messages of the ST and abandoning its rhetorical nuances, thus producing what I regard as a minimalist rendition.

Reiss, who pioneered functional translation theory, contended that "the transmission of the predominant function of the ST is the determining factor by which the TT is judged" (Reiss 1989: 109). Knowing what I know of the official translators and staff on Xinhua News and/or AP, there is reason to believe that the news agencies see the maxim primarily as a political message whereas the official translators see it not only as a political message but also as an expression of the artistic charismas of a political leader. There is also sound reason to believe that, to the journalistic translators, newsworthiness, immediacy and potential for controversies rather than "fidelity" in meaning, spirit and form may have been of a major concern. In other words, the journalistically flavoured renditions may be seen as perfectly correct in the light of the functional and skopos translation theory.

But an important question is, in the official Chinese discourse of translation, how did the two official translators overcome the many difficulties, which they apparently had adequate appreciation of, in order to accomplish the "correct" translation without adding anything to or losing anything of the ST? I will present my critical analysis of how they made the "correct" translation in the next section of this paper. First, I will provide a summary of Ding's and Lin's own accounts of strategies.

Ding (2006) observes that he firstly sought for "the true spiritual essence" of the maxim by "acquiring a lofty thought" and by "undertaking an in-depth political study." He then strove to appreciate "the depth of the leader's directives which translators must strive to comprehend." Thus he got much "enlightenment," including that "many people living in the outback of China do not have quality schooling due to objective circumstances. These people cannot be described as 'those who remain ignorant' but rather as 'those who prefer to be ignorant"' (which was later revised to "those who refuse to be educated" in the TAC version). He then managed to rewrite the leader's directives in idiomatic English. "For example, in the context of the maxim, 'shame' is seen as a more idiomatic word than 'dishonour' or 'disgrace." As importantly, he claims to have used the correct and elegant style of English. "The supreme leader's direction must be translated into solemn but not archaic English." In short, "standing in a lofty position, understanding the depth of the ST, writing in elegant language and using a beautiful style" were seen as crucial by Ding for translating "Honours/Shames" 
correctly. The strategies, which Lin (2006) claimed to have used, were quite comparable to those of Ding except that the latter seemed to have paid additional attention to the reproduction of rhetorical features of the ST, including the translation of positive/ negative words, idioms, parallel structure, symmetry and rhythms.

\section{How is the "Correctness" Constructed in Translation?}

Is any one of the renditions sampled in this paper correct or flawed? Or is any one more correct than any other one? These are not questions being addressed by this paper? Not do I believe that anyone, official translators or academics like me included, has the natural authority to do this. More likely different people have different evaluations and readers of this paper will also form their own opinions whether or not they are influenced by my analysis and reasoning. It is clear, however, that Rendition [2] is drastically different from [3] and [4]. Knowing that the former is judged as "flawed" and the latter two as "correct" in the dominant Chinese discourse of translation, it is possible to, by comparing them, accomplish my research aim of acquiring an enhanced appreciation of the discourse, which I have already tried to do in the preceding discussions. Next, I will proceed to a summary of the requirements of correct political translation.

First of all, a correct translation of a political text must be grammatically more maximalist and complex, being loaded with a high number of words and rather complicated sentence structures and nothing whatever of the ST, semantically, structurally or rhetorically, is omitted. A grammatically less complex translation has a higher probability of being considered flawed and problematic. Generally speaking, Rendition [2] uses vernacular English phrased in simple sentence patterns and, wherever possible, avoids repetition by using pronouns, e.g., "her" for "motherland" and "them" for "people," or by using omissions, e.g., "Love, do not harm the motherland." By contrast, Renditions [3] and [4] emphatically use grammatically more complete and pedantic English phrased in a compound sentence pattern marked by "who" and repetitions, e.g., "honour to..." and "shame on..." in every sentence.

Next, a correct translation of a political text must be structurally symmetrical and repetitive and an unsymmetrical structure is likely to be seen as flawed and unrefined. The symmetry/repetition appears to be complete in Renditions [3] and [4] where each and every pair of statements is structured on the basis of the same sentence pattern (i.e., "...those who...") and repetitively uses the same words in the same pattern (i.e., "honour to those who..." and "shame on those who..."). The use of punctuation marks is apparently intended to enhance symmetry, with comma within each pair and semi-colon between pairs in Rendition [3] and comma within each pair and period between pairs in Rendition [4]. With no conjunction marker (e.g., "and") and split into two lines in Rendition [4], the two statements/clauses within each pair are notably of about the same length and the same quantity of words/syllables. If the two statements/clauses have to be of different lengths, the preceding one is shorter than the rear one to avoid looking top-heavy. This duplex structure is very similar to that of a major conventional Chinese poetic genre and I will further discuss this poetic resemblance in the next paragraph.

Still next, a correct translation of a political text must preserve the rhetorical features of the ST and must represent them in preferably longer phrases, more erudite 
and infrequent vocabulary. Loss of a ST rhetorical feature is likely to mark a translation as flawed and uncultured. One of the rhetorical devices paid much attention to is contrast, i.e., using antonyms to dichotomise reality into either "honour" or "shame," "loving" or "harming" the motherland and either "serving" or "betraying" the people, etc. In the rhetorical convention of modern Chinese, words are classified into those with positive connotations and others with negative connotations. Strictly the former must be used in reference to good people/things and the latter in reference to bad people/things, which is the case with the Chinese ST of "Honours/Shames" and with the two "correct" translations sampled in this paper. ${ }^{13}$

Furthermore, a correct translation must contain special treatment of idioms used in the political ST because, as Lin (2006) puts it, they are an important element in Chinese rhetoric. Idioms are also a rhetorical construct and I have singled it out for discussion because of their cultural value in Chinese. Chinese idioms are usually four-character words containing morals constructed on the basis of historical legends and/or personalities (e.g., Mencius) and accordingly are usually seen as an indication of the cultivation of their users. "Honours/Shames" contains many idioms including: 好逸恶劳 (loving comfort hating work) and 违法乱纪 (breaking law disrupting discipline). They could be translated into the kind of common plain English as used in Rendition [2], such as “indolent” or “being lazy and hating work” for 好逸恶劳 and “chaotic and lawless" for 违法乱纪. But according to Lin (2006), authors of Renditions [3] and [4] strove vigorously to translate the many idioms of "Honours/ Shames" into so-called "erudite English." That is, more studious words (e.g., "indulging in comfort and hating work" for 好逸恶劳) and longer and more complicated collocations (e.g., “being undisciplined and breaking the law” for 违法乱纪) are used. Apparently, only complex and pedantic English writing is thought to match the supernatural knowledge, wisdom and cultivation of the supreme leader even though, in my judgment, idioms may actually be seen as clichés or even as an indication of lack of abstract thinking.

Additionally, however faithful it must be, a correct translation must hide or neutralize whatever abnormalities it may seem to have, which may have potentials to alienate international subjects. "Honours/Shames," though stated in descriptive and factual-looking sentences about some seemingly universalist moralities and values, is a de facto list of commandments addressing the Chinese subjects directly. This speech act, i.e., cautioning people with cultivated language, is known as euphemism in rhetoric and I would personally think that euphemism is plentiful in Chinese political and social activities where persuasion is now increasingly accepted as more effective than coercion. Xinhua News appeared to have read through the euphemism and translated the actual message, when it presented a list of do's and don'ts. But the official translators would never do this as they are fully aware that the maxim is intended only for their compatriots to grasp unmistakably beyond the euphemistic guise and the do's and don'ts may look excessively nosy and intrusive to English speaking citizens living in other jurisdictions. So, rather than conveying the message of the maxim faithfully, i.e., giving commandments, Renditions [3] and [4] have chosen to translate the euphemism, i.e., saying what the maxim seems to say.

Understandably, I must add that achieving all the above, i.e., writing grammatically, reflecting the symmetry, reproducing the rhetoric's, keeping the idioms and dressing up the leaders, will result in a maximalist translation. Berman (2000) 
noted that translation tended to expand the ST. Zhong conducted a case study of subtitling and dubbing by China Central Television, which confirmed this expansive tendency which he described as maximalist (Zhong, 2008). The two "correct" translations sampled for this paper have taken this maximalist tendency to an extreme, containing twice as many words (145 in [3] and 139 in [4]) as the "flawed" one (71 in Rendition [2]).

\section{Summary: What Does the "Correct" Translation Tell Us?}

In this paper, I discussed a maxim issued by the current supreme leader of China, which has been translated and published repeatedly. I started by defining leadership qualities and by isolating three of them relevant to the discussion of this paper. I went on to explain that $\mathrm{Hu}$ is not alone, that Chinese political leaders have a tradition of governing by maxims, that political maxims have a tradition of being poetically dressed up and that, consequently, Hu's oeuvre is not only semantically but also structurally and rhetorically sophisticated. I then presented a number of renditions of the maxim, including one seen as flawed and two claimed to be correct, which I had sampled and analysed for the purpose of this paper. By analysing and comparing the samples, I addressed a series of questions. What are the criteria of a "correct" translation? What is a "correct" translation like, structurally, rhetorically and semantically? How is a "correct" translation made? What strategies are used to accomplish "correctness"? What makes a translation look "flawed"? How do "flawed" translations compare to "correct" translations"?

By addressing the questions, I was able to shed light on the current dominant Chinese discourse of translation, especially with regard to "correct" translation of texts by political leaders for international readers. Phrased in a nutshell, a "correct" translation must be faithful in every bit to the ST, not omitting even a single iota of it, semantically, structurally and rhetorically. Much of the emphasis is on the reproduction of the structure and rhetoric of the ST. As a result, a "correct" translation

a) is structurally loaded with complex syntactic structures and difficult vocabularies including especially pedantic words and phrases;

b) duplicates the original rhetorical features (e.g., symmetry, contrast, idiom and euphemisms) of the Chinese ST;

c) covers up or dresses up those elements of the ST not intended for international readers;

d) must have the quality required for enhancing the charismas of authors; and

e) often looks maximalist and bulky as a result of having to achieve the above.

This list, which recaps the discussion of the preceding sections, embodies the dominant Chinese discourse of translation. It may be very critical but it is truly based on analyses of the so-called "correct" translation and documented justification of "correct" translation. Before concluding this paper, I would like to add that, ironically, even the official translators know that their "correct" translations are not necessarily correct when, in the words of Ding (2006), translators must take care of the "height," "depth," "strength," "gracefulness" and "beauty" of supreme leaders' words, all of which would signal biases to most people. 


\section{NOTES}

1. I am indebted to my student Gyongyi Horvath whose works drew my attention to aspects of leadership qualities.

2. The information is sourced from Baidu. Visited on 31 September 2011, <http://zhidao.baidu.com/ question/4173286.html>.

3. The information is sourced from Baidu. Visited on 31 September 2011, <http://zhidao.baidu.com/ question $/ 7701109 . \mathrm{html}$ ?si $=4>$.

4. On the Correct Handling of Contradictions among the People was first published in 1957 and was republished in Mao (1991, Vol. 5, 367-368). English translation by anonymous translator retrieved from Origo. Visited on 31 September 2011, <http://art-bin.com/art/omao4.html>.

5. Olesen, Alexa (16 March 2006): Chinese President Hu Issues List of Virtues: One Is 'Don't Be Lazy and Hate Work.' China Forum. Visited on 31 September 2011, <http://bbs.chinadaily.com.cn/ viewthread.php?action $=$ printable \& $\mathrm{tid}=507865>$.

6. MAO, Zedong (1939): Snow. Visited on 31 September 2011, <http://zhidao.baidu.com/question/ 29349957.html?an=0\&si=1>. English translation by anonymous translator available on Baidu. Visited on 31 September 2011, <http://zhidao.baidu.com/question/8004648.html?fr=qrl3>.

7. A official video interpretation/representation of the maxim can be seen on Youku. Visited on 31 September 2011, <http://v.youku.com/v_playlist/f986429olp0.html>.

8. More information about Anna Louise Strong (November 24 1885-March 29 1970), an American, can be found at: <http://en.wikipedia.org/wiki/Anna_Louise_Strong $>$.

9. ZHANG, Zhiyi (2006): 南开大学师生座谈 “八荣八耻” [Staff and students of Nankai University discussing Hu's maxim]. Tianjin Daily. Visited on 31 September 2011, <http://news.enorth.com. $\mathrm{cn} / \mathrm{system} / 2006 / 03 / 20 / 001259212 . s h t m l$.

10. HE, Wenchao (2006): “八做八不做” - - 品格教育课程设计的机遇 [“Eight Do's and Eight Don'ts - An opportunity for character education curricula design”]. 何文超个人博客 [Blog of Wenchao He]. Visited on 2 January 2008, <http://www.hewenchao.com/Article_Show.asp ArticleID=195>.

11. Chinese papers describing the efforts can be found at a range of World Wide Web pages, including the following: <http://www.yxzzxx.com/jstd/ShowArticle.asp?ArticleID=125> and <http://www. jysls.com/viewthread.php?tid=147600>.

12. The three criteria were first theorized by Fu Yan, quoted in Fan (1986). Considering the literal meaning of these words, I see them as equivalent to "fidelity" and "correctness" in the context of this paper. For a linguistic perspective into the terms, see Chao, Y. R. (1969).

13. Antonyms are not always available in English and many other discursive systems. But this absence of antonyms seemed to be unbelievable to the official translators in their search for one for "science." He would be even more surprised should he discover that science may even be looked at with scepticism and criticism in association to scienticism. Nevertheless, Lin is committed to a "continuous search for a correct antonym to science" (Lin 2006: 81).

\section{REFERENCES}

Austin, John (1975): How to Do Things With Words. Cambridge: Harvard University Press.

BARMÉ, Geremie (1996): Shades of Mao: The Posthumous Cult of The Great Leader. Armonk: M.E. Sharpe.

Baumgartner, Richard (1989): Strategies of Political Leadership in Diverse Settings. In: Bryan Jones, ed. Leadership and Politics: New Perspectives in Political Science. Lawrence: University Press of Kansas, 114-134.

BeLL, Roger (1991): Translation and Translating: Theory and Practice. Harlow: Longman.

Berman, Antoine (2000): Translation and The Trials of The Foreign. In: Lawrence Venuti, ed. The Translation Studies Reader. London/New York: Routledge, 284-297.

Bloodworth, Dennis (1982): The Messiah and the Mandarins: Mao Tse-tung and The Ironies of Power. New York: Atheneum.

CHANG, Yuanyuan (2004): 谈谈领导人言论英译的几个问题 [On several issues of translating the utterances of leaders]. Chinese Translators Journal. 25(1):55.

ChAo, Yuen Ren (1969): Dimensions of Fidelity in Translation With Special Reference to Chinese. Harvard Journal of Asiatic Studies. (29):109-30.

Cheng, Zhenqiu (2004): 政治文献的翻译 [On the translation of political documents]. Chinese Translators Journal. 25(1):50. 
Cherniss, Cary (2006): Leadership and Emotional Intelligence. In: Ronald Burke and Cary COoper, eds. Inspiring Leaders. Abingdon/New York: Routledge, 132-148.

CHINA TRANSLATORS' ASSOCIATION (2006): 中国译协对外传播翻译委员会中译英小组讨 论词汇 [Standard translation published by Chinese-English-Translation Group of Outward Propaganda and Translation Committee of China Translators' Association]. Chinese Translators Journal. 27(3):95.

Deng, Xiaoping (1993): 《邓小平文选》[Deng Xiaoping's Selected Works]. Beijing: People’s Publishing House.

Ding, Hengqi (2006): “八荣八耻” 的英文翻译 [On translating “Eight Honours and Eight Shames"]. English Study, posted on 15 September 2006. Visited on 31 September 2011, $<$ http://edu.qq.com/a/20060915/000145.htm>.

FAN, Shouyi (1986): 评翻译界五十年的争论 [Reviewing A Fifty-Year Long Debate]. Chinese Translators Journal. (1):2-8.

Gardner, Howard and Laskin, Emma (1995): Leading Minds: An Anatomy of Leadership. New York: Basic Books.

Grove, Andrea (2007): Political Leadership in Foreign Policy: Manipulating Support across Borders. New York/Basingstoke: Palgrave Macmillan.

GutT, Ernst-August (2000): Translation as Interlingual Interpretive Use. In: Lawrence Venuti, ed. The Translation Studies Reader. London/New York: Routledge, 376-396.

Jenner, William (1990): Insuperable barriers? Some Thoughts on The Reception of Chinese Writing in English Translation. In: Howard Goldblatt, ed. Worlds Apart: Recent Chinese Writing and Its Audience. Armonk: M. E. Sharpe, 177-197.

Jiang, Zemin (2006): 《江泽民文选》 [Jiang Zemin's Selected Works]. Beijing: People’s Publishing House.

LiN, Wusun (2006): 有关 “八荣八耻” 翻译的讨论和思考 [Discussions and reflections on translation of “Eight Honours and Eight Shames"]. Chinese Translators Journal. 27(5):80-81.

MA, Shikui (2006): 文学输出和意识形态输出一 “文革” 时期毛泽东诗词的对外翻译 [Exporting literature and ideology - Externally oriented translations of Mao Zedong's poems during the "Cultural Revolution"]. Chinese Translators Journal. 27(6):17-23.

MaO, Zedong (1991): 《毛泽东选集》 [Mao Zedong's Selected Works]. Beijing: People’s Publishing House.

Midlarsky, Manus (1989): Leadership in The International System: Bismarck and Washington Compared. In: Bryan Jones, ed. Leadership and Politics: New Perspectives in Political Science. Laurence: University Press of Kansas, 189-207.

Nye, Joseph (2008): The Powers to Lead. New York: Oxford University Press.

QIU, Ke-an (2004): 古诗文英译问题 [On the question of translating ancient poetry and prose]. Chinese Translators Journal. 25(1):51.

ReIss, Katharina (1989): Text Types, Translation Types and Translation Assessment. (Translated by Andrew Chesterman). In: Andrew Chesterman, ed. Readings in Translation Theory. Helsinki: Finn Lectura, 105-115.

Sun, Wanning (1996): In Search of New Frameworks: Issues in The Study of Chinese Media In The Era Of Reform. Media International Australia. (79):40-48.

WANG, Naosheng (2004): 十六大报告汉英翻译的几点思考 [Reflections on English translations of the " $16^{\text {th }}$ Chinese Communist Party Congress Report"]. Chinese Translators Journal. 25(1):56-59.

WEI, Meiya (2004): 《毛主席语录》出版揭秘 [Revealing the secrets of the publishing of Mao Zedong Selected Works]. 《党史纵横》 [A chronological and synchronic account of Chinese Communist Party]. 7:5-11.

YANG, Zhengquan, et al., eds. (1999): 中国外文局50年回忆录 [Fifty years at China foreign language bureau, a biography]. Beijing: Xinxing Publishing House.

Zhong, Yong (2008): Taming The Desperate Housewives. Across Languages and Culture. 2(2):203-220. 